University of Louisville

ThinkIR: The University of Louisville's Institutional Repository

Electronic Theses and Dissertations

$6-1938$

\title{
A cytological study of the ciliated epithelium of Nucula castrensis Hinds.
}

Dorothy Blumer

University of Louisville

Follow this and additional works at: https://ir.library.louisville.edu/etd

Part of the Aquaculture and Fisheries Commons

\section{Recommended Citation}

Blumer, Dorothy, "A cytological study of the ciliated epithelium of Nucula castrensis Hinds." (1938).

Electronic Theses and Dissertations. Paper 1871.

https://doi.org/10.18297/etd/1871

This Master's Thesis is brought to you for free and open access by ThinkIR: The University of Louisville's Institutional Repository. It has been accepted for inclusion in Electronic Theses and Dissertations by an authorized administrator of ThinkIR: The University of Louisville's Institutional Repository. This title appears here courtesy of the author, who has retained all other copyrights. For more information, please contact thinkir@louisville.edu. 


\title{
UNIVERSITY OF LOUISVILLE
}

\section{A Cytological Study of the Ciliated Epithelium of Nucula castrensis Hinds}

\author{
A Dissertation \\ Submitted to the Faculty \\ of the Graduate School of the University of Louisville \\ In Partial Fulfillment of the \\ Requirements for the Degree \\ of Master of Science
}

Department of Anatomy

By

Dorothy Blumer

1938 
NAME OF STUDENT:

TITLE OF THESIS: A CYTOLOGICAL STUDY OF THE CILIATED EPITHELIUM OF NUCULA CASTRENSIS HINDS

NAME OF DIRECTOR:

APPROVED BY A READING COMMITTEE COMPOSED OF THE FOLLOWING:

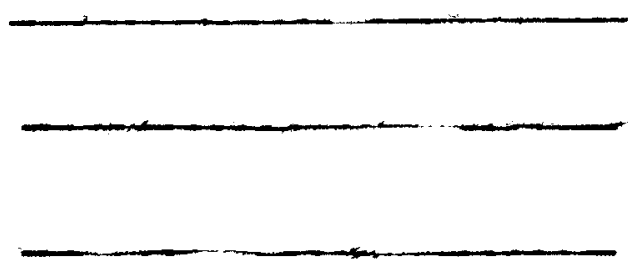

REPRESENTATIVE OF THE

DEPARTMENT OF ENGLISH

DATE: fune 1938 
Contents

I Introduction.................... page 1

II Review of Literature............... page 3

III Materials and Methods................ page 6

IV Observations..................... page 8 General description of animal and gills.... page 8 General description of cells studied....... page 13 Lateral cells................ page 14 Laterofrontal cells............ page 22 Frontal cells............... page 26 Marginal frontals....... page 30

v Discussion....................... page 33

VI Summary...................... page 46

VII References...................... page 48 
I Introduction 


\section{Introduction}

Ever since the latter part of the 17th century, when clliary movement was first observed, the study of clliated colls has been of great interest to biologists, particularIy to physiologists. In 1713 Leeuwenhoek recorded some observations he made on clliary activity, using his primitive microscope.

A knowledge of the structure and function of ciliated cells is also of importance in that branch of medicine pertaining to disorders of the resplratory passages and the movement of the ovum in the uterine tubes.

The bivalve molluses have come to be the classical example for the study of ciliated cells, both because of the convenience of working with them and because their clilated surfaces are quite extensive, since this group of animels depends largely on clliary activity for food and respiration.

Almost all of the previous investigations have been carried out on higher forms, the filibranchs, pseudolamelifbranchs and eulamellibranchs, all of which have highly specialized cillated cells. This peper is concerned chiefly with a study of the cytology of the cells of the gills of a primitive protobranch, gills which are largely for respiration and not so much for food-collecting. These feather-form gills are small and not so highly specialized as those of the higher bivalves. 
An attempt will be made to see if the cellular structure is more primitive than in the more specialized forms previously examined, and to discover, if possible, the lines along which specialization has taken place. 
II Review of Iiterature 
Review of Literature

As alreudy mentioned, most of the papers dealing with the subject of clliated epithellum are more concerned with the physiological reactions of the cells than with their cytology. The question of whether or not clliary movement is under the control of the nervous system has been the chief object of many investigations. Anong those who have found evidence indicating that the nervous system of the animal does have some influence over cliliary activity are Carter (126) who found nerve fibers in the ciliated epithelium of the velum of the nudibranch veliger and described and pictured their nerve endings in the ciliated cells.

McDonald, Leisure, and Lenneman (128) found that they could greatly accelerate or retard the rate of beat of the cilla of the epthelium of the frog's pharynx by stimulating the sympathetic or parasympathetic fibers innervating this epithelium or by the use of drugs which simulate the sympathetic or parasympathetic nervous systems.

Grave and Schmitt (1.25) described, in the laterofrontal epithelium of a lanellibranch gill, a rather complicuted system of intracellular fibrils along which they believed the impulses both for coordination and regulation may pass.

The observations of Wyman (125) support the theory 
of "neuroid transmission" as first expressed by Parker In 1919, when he spoke of the "elementel property of protoplasmic transmission."

Lucas ('31) also concluded that the nervous system is not directly involved in ciliary reactions, since he could not definitely trace any fibers from the central nervous system to the gill leaflets.

Gray's work on cllia (124) has been chiefly the study of the effects of temperature, ionization, oxygen consumption and other environmental influences upon cillary activity. Proetz (134) has shown the effects of various drugs on living nasal eplthelium in the rabbit.

Atkins (136) was interested primarily in the sorting mechanisms and clliary currents of various lamellibranchs. She considered the gill of Nucula to be probably the most primitive type to be found among living lamellibranchs and says (quoting orton, 1912) ${ }^{2}$ that it "presents an early stage in adaptation of the original respiratory organ to a food-collecting organ."

The obgervations of Engelmann ( 180 ) were probably the first significant contribution to the study of

1. Parker, G. H. The Elementary Nervous System. J. B. Lippincott, Philadelphia. 1919. p. 65.

2. Orton, J. H. Mode of Feoding of Crepidula, and in Gastropods and Lamellbranchs. J. Mar. Biol. Assoc., vol. 9, pp. 463-464. 1912 . 
ciliated epithelium from a cytological standpoint. Using only living and macerated preparations, he saw and described even the arrangement of the basal bodies and the intracellular fibrils. In the laterofrontal cells, or "Eckzellen," he recognized the two parallel rods seen in surface view as belng composed of fused basal bodies, and discovered that two nembranelles of cllia arose directly from these rods and not from between them as Posner had asserted several years before, in 1877 .

Frenzel (136) also described in detail the clilary apparatus in a variety of molluscs and annelids. Saguch1's paper (117) gives a complete account of the structure of clilited eolls.

Detailed descriptions of the structures of the gills of lamellibranch molluscs may be found in the paper of Peck (177). Drew (101) studied thoroughly the embryological development of gills. 
III Materials and Methods 
Materials and Methods

The cillated cells studied in the present investigation were obtained from the gills of the protobranch, Nucula castrensis Hinds, collected at Friday Harbor, Washington, in the summer of 1936. Ciliary activity was observed in the living gills after they were colored wth neutral red and toluidin blue dissolved in sea water.

Gills were removed from a number of the animals and fixed by several different methods: Champy's fluid, plus after treatment with pyroligneous acid and potassium bichromate; Flemming strong plus acetic acid; Boeke's method; 10\% formalin; and Bouin's solution were the fixatives employed. Several of the animals were partly opened and stupified in megnesium sulfate-saturated sea water for one hour, and a few were put into sea water containing a small amount of magnesium sulfate for three or four hours. Both of these groups were then fixed in Bouin's solution. The Champy and Fleming flxed material was embedded in paraffin containing $4 \%$ Bayberry wax, sectioned serially at three, four, and five microns, and stained by the following methods: Heidenhain's ironhaematoxylin, Benda's sulfalizarinate method, Safranin-0 and fast green, and the Champy-Kull staln. The Heldenhain iron-haematoxylin stain on the Champy fixed material mounted in Euparal vert gave probably the most consistently satisfactory results.

Some of the Bouin flxed gills were used in making 
whole mounts of the leaflets, stained in Mayer's alcoholic acid carmine and weak fast green. A fow of these leaflets were dissected under the binocular microscope into very minute fragments. The formalin material furnished frozen sections which were stained by the pyridine silver method to determine the possible presence of nerve endings. Several slides from the Champy material were mounted unstained in Euparal vert for the observation of the Golg1 apparatus.

It may be stated here that the results of the methods for the presence of the Golgi apparatus and nerves were negative for all of the cells.

Most of the microsconical work was done with apochromatic optical equipment and different combinations of colored Wratten filters.

The number of rows of cilia were counted in the lateral cells, and the size of the various cells and the length of the clila were ascertained by means of a Bausch and Lomb fllar micrometer.

All of the photographed figures were drawn with the aid of a camera lucida at magnifications ranging from 100 times to 2900 times. When photographed, these drawings were reduced two-fifths of the original size. The photographs of the whole animal were made with a $64 \mathrm{~mm}$. Leitz microsummar with a magnification of about 5 diameters. The photographs of the gills were taken with a $35 \mathrm{~mm}$. Leitz microsummar and are magnified 11 times. 
IV Observations 
Observations

Nucula castrensis Hinds is a small somewhat ovalshaped bivalve averaging $16 \mathrm{~mm}$. in the anterior-posterior length of the shell and $14 \mathrm{~mm}$. from the umbo to the inferior border of the shell (Fig. 1).

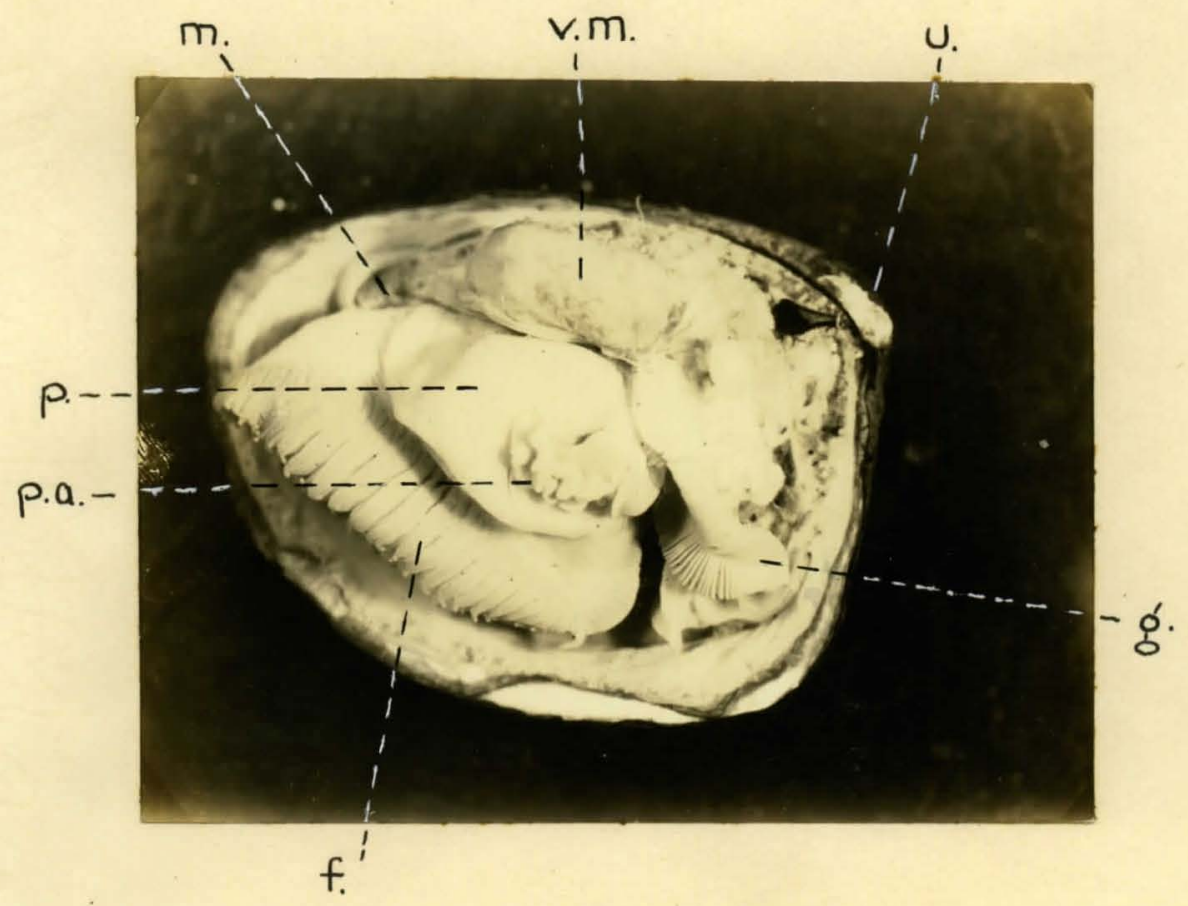

FIGURE 1

Photograph of a whole animal with the left valve removed. f., foot; g., gill; m., region of mouth; p., palp; p.a., palp appendage; u., region of umbo; v.m., visceral mass. $\mathrm{X} 5$.

It lives beneath the surface of the sand which is its habitat. The gills are chiefly for respiration, while the relatively huge palps and palp appendages serve as the principal food-collecting organs, the food being conveyed to the mouth by the palp appendages. It 
is customary in deposit feeders of this type for the gills to be small and the palps large, as is the case in Nucula (Atkins, '36).

In Nucula, the gills, of which there are two in each animal, one on each side of the body, are about $6 \mathrm{~mm}$. long. Mitsikuri (181) says "the gill in Nucula is of quite an exceptional nature. It does not, as in most lamellibranchs, extend along the whole length of the side of the body, constituting the most important object of the mantle cavity, but is comparatively inslgnificant."

The gills are suspended by membranes and appear to be attached anteriorly to the tough band of tissue lying directly beneath the visceral mass. The posterior ends of the gills lie free in the mantle cavity. The suspensory membrane does not reach entirely to the posterior tip of the gills, five or six leaflets extending beyond its attachment.

Each gill is made up of lateral and medial gill leaflets attached to a micrib portion. The number of pairs of leaflets varies, from 90 to 112 pairs having been counted in several specinens. The shape and size of these leaflets also differ, those leaflets in the middle of the gill being larger and decreasing in size toward both onds (Figs. 2 and 3 ). 


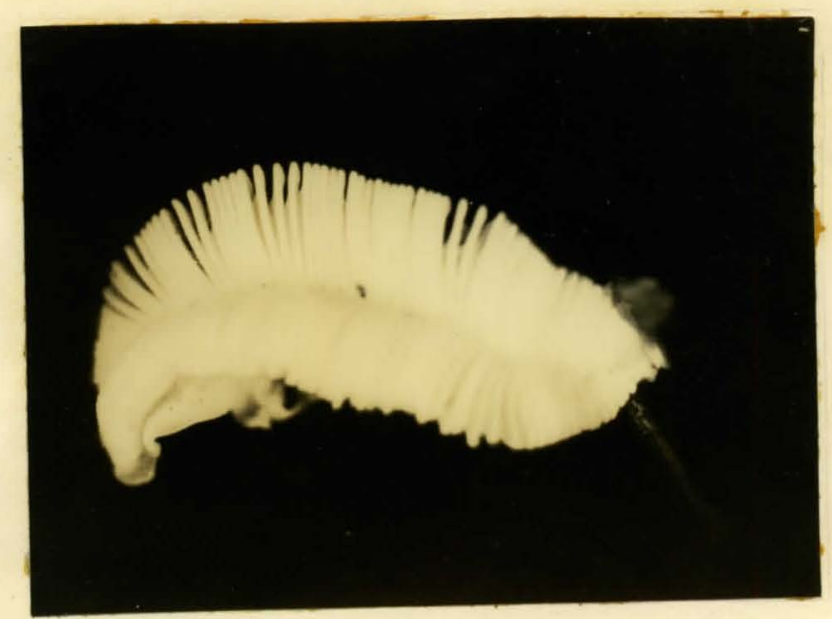

FIGURE 2

Photograph of right gill viewed from frontal surface. X 11 .

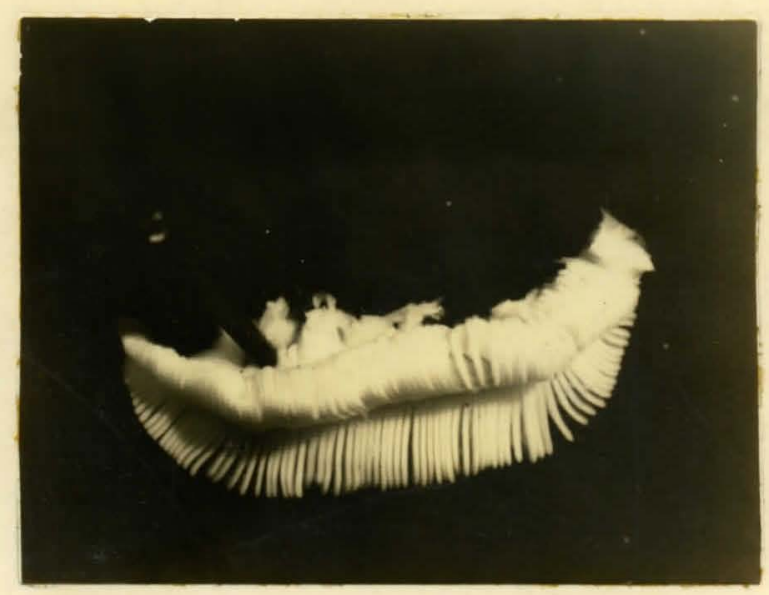

\section{FIGURE 3}

Photograph of right gill. Lateral leaflet toward camera. X 11.

Figures 2 and 3 are photographs of the same right 
gill. Figure 2 is looking directly on the inferior or frontal surface, the anterior end of the gill to the right side of the picture. The lateral filaments are above the midrib, and the medial. leaflets below. Figure 3 was taken with the edge of the lateral filaments facing the camera. Again the anterior tip of the gill is to the right. The abfrontal or dorsal surface of the leaflets is opposite that shown in the figures and is only slightly clliated. This area is shown, however, in figures 4 and 5. The medial and lateral leaflets differ slightly In shape, the outer being somewhat shorter and thicker than the inner ones (Figs. 4 and 5). At the free dorsal tip of each medial leaflet there is a knob-like structure covered with long clila. (Fig. 5, to the left of the label abf.s.). Th1s gives a ridged appearance to the inner edge of the gill when it is viewed from this side.

The leaflets of Nucula are easily separable, indicating that there are no strong ciliary functions as are present in some other protobranchs (Atkins, '36). The musculature of the gill filaments is also much less extensive in Nucula, being confined to a few fibers lying under the abfrontal surface. 


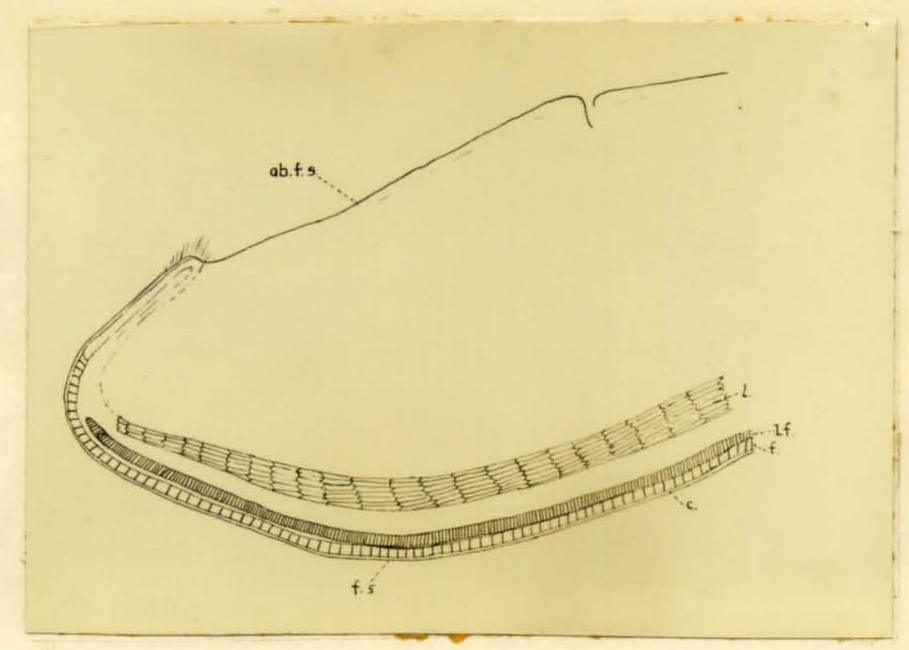

\section{FIGURE 4}

Medial leaflet of gill. ab.f.s., abfrontal surface; c., cuticle; f., frontal epithelium; f.s., frontal surface; 1., lateral epithelium; 1.f., láterofrontal epithelium. Bouin's fix. Carmine and fast green. $X 60$.

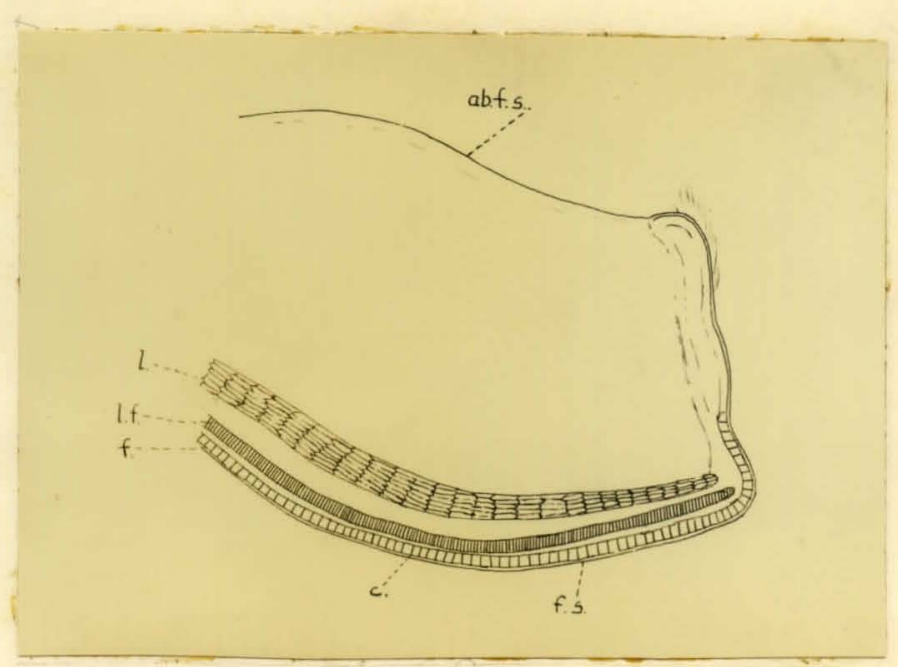

\section{FIGURE 5}

Lateral leaflet of gill. Lettering same as for Fig. 4. Bouin's fix. Carmine and fast green. $X 60$. 
The three types of ciliated cells studied in this paper are the lateral, laterofrontal, and frontal, emphasis being placed on the laterals, which were compared with similar cells in Ostrea, a highly specialized lamellibranch studied previously by Dr. Jack Chumley.

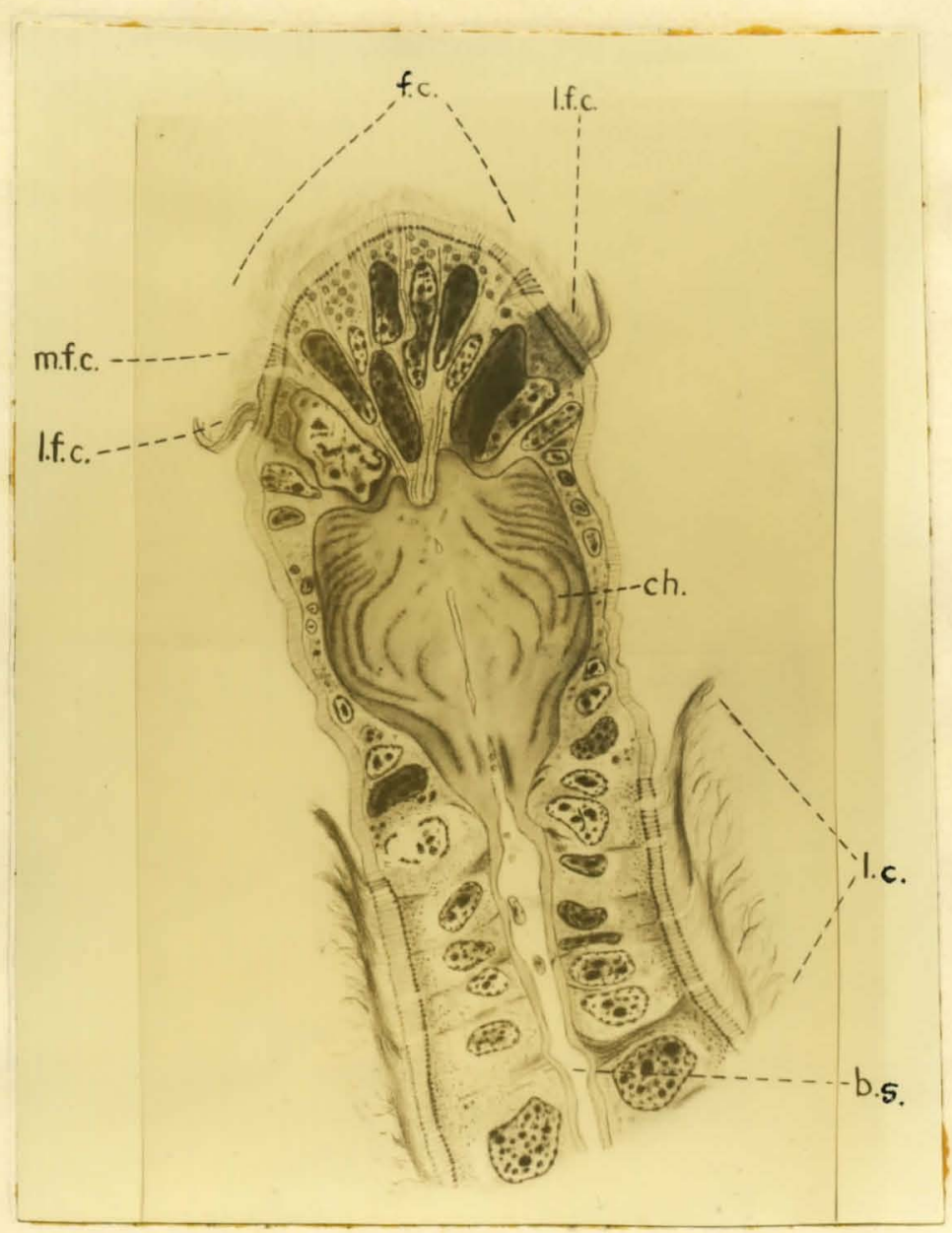

FIGJRE 6

Transverse section of part of a single leaflet. b.s., blood space; ch., chitinous supporting tissue; f.c., frontal cllia; l.c., lateral cilia; l.f.c., laterofrontal cilia; m.f.c., marginal frontal cilia: Champy fix. Heidenhain's iron-haem. $\mathrm{X} 816$. 
We will consider in order the lateral cells, next the laterofrontal cells, and, lastly, the frontals (Fig. 6). Laterals. The lateral cells form a band seven to eight cells wide on each side of the leaflet near the frontal surface. This band measures 50 to 56 microns in width and is probably the widest lateral epithelium found on any of the protobranch or lamellibranch gills thus far studied (Fig. 7).

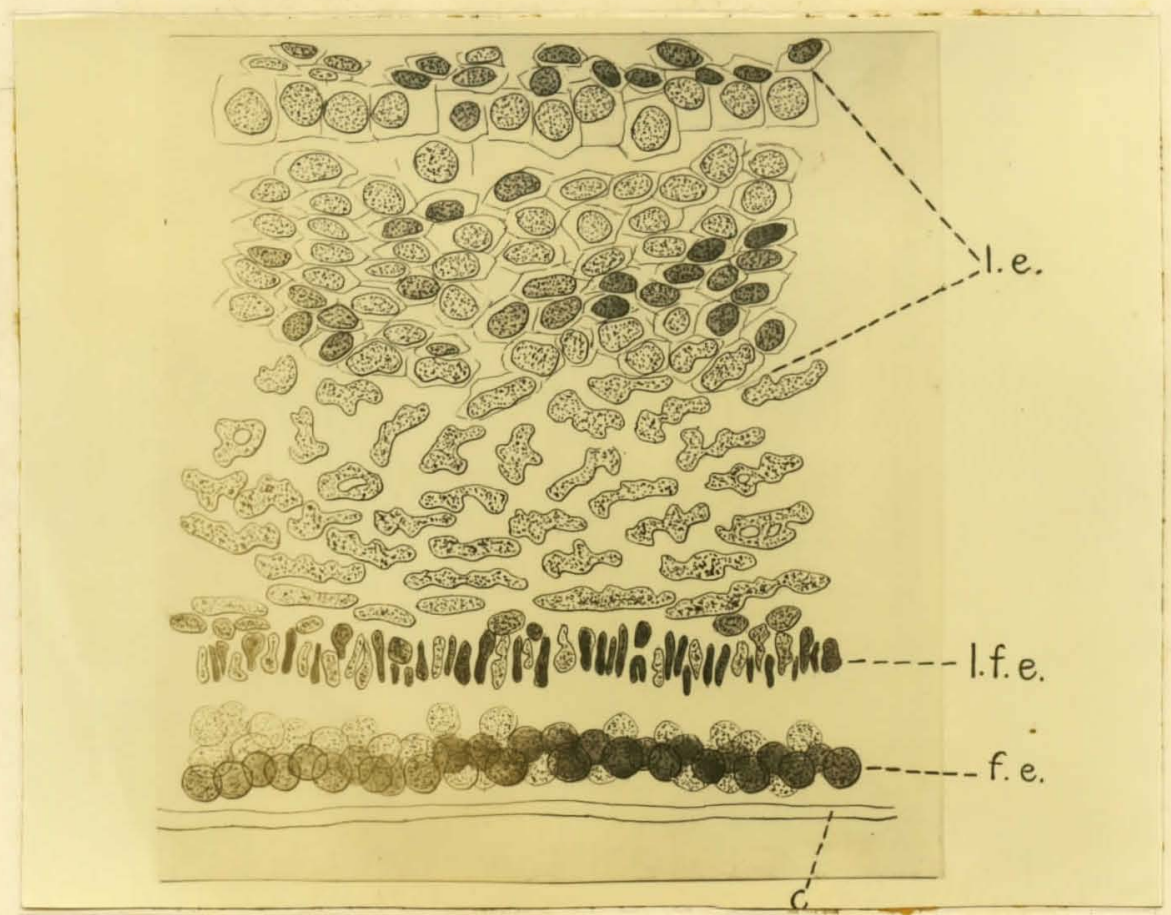

FIGURE 7

Surface view of part of lateral leaflet drawn from a whole mount. c., cuticle; f.e., frontal epithelium; l.f.e., laterofrontal epithellum; 1.e., lateral epithelium. Bouin's fix. Carmine and fast green. Deep focus to show nuclei only. X 516 . 
The effective beat of the lateral cilia is toward the abfrontal surface (Fig. 6), while the wave of conduction is at right angles to this, in the length of the lateral band as indicated in diagrammatic figure (A). The short arrows represent the wave conduction of the laterals and the long arrows indicate the direction of wave conduction of the frontals. The

\section{Posterior}

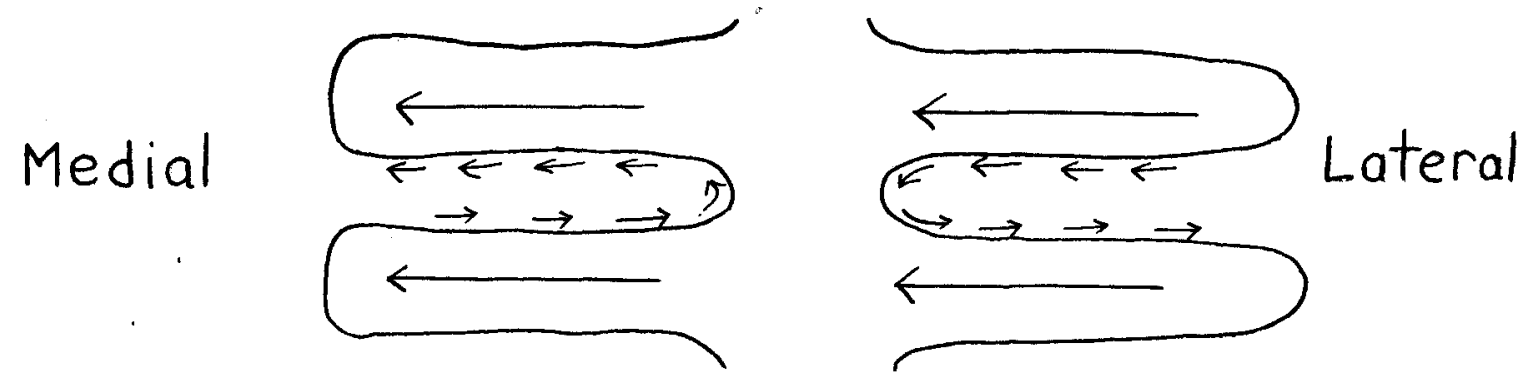

\section{Anterior}

FIGURE A

Four leaflets viewed from the frontal surface of the gill.

currents produced by the lateral cilia are for the movement of water for respirution.

Sections were cut to show the cells in frontal, lateral, and surface views. Frontal view of a cell is defined as that aspect of the cell seen when examined in the direction of the effective beat of the cilia. 
Iateral view is at right angles to the frontal, and the surface view is horizontal.

The lateral cells in frontal view are seen in longitudinal sections of the leaflets, the plane of sectioning being at right angles to the effective beat of the cilia and in the direction of the wave movement. In the lateral view the leaflets were cut transversely and along the axis of the effective beat of the cilia. The surface view might be called an airplane view, that is, looking directly down on the upper surface of the cells.

In the longitudinal sections the lateral cells are high cuboidal in shape, measuring about 16 microns high and 11 microns wide (Fig. 8). They rest upon the

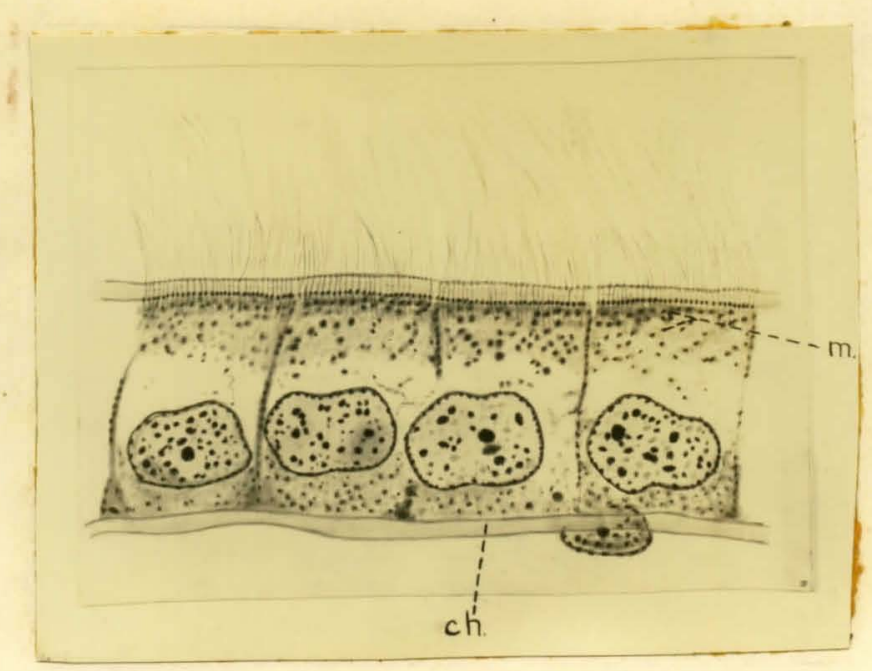

FIGURE 8

Frontal view of lateral ciliated epithelium. ch., chitinous support; m., mitochondria, Flemming's fix. Heidenhain's iron-haematoxylin. X 1380 . 
chitinous supporting structure of the filament with their longer dimension in the plane of the epithelial row. The nuclei, which lie in the basal portion of the cells, are somewhat potato-shaped in this view. They are around 9 microns wide and 5 to 6 microns high, often being slightly constricted in the middle. Chromatin is clumped around the periphery of the nuclei and at least one large karyosome is present in each nucleus.

In lateral view the cells are tall columnar, measuring 5 microns in width (Fig. 9). The nuclei also

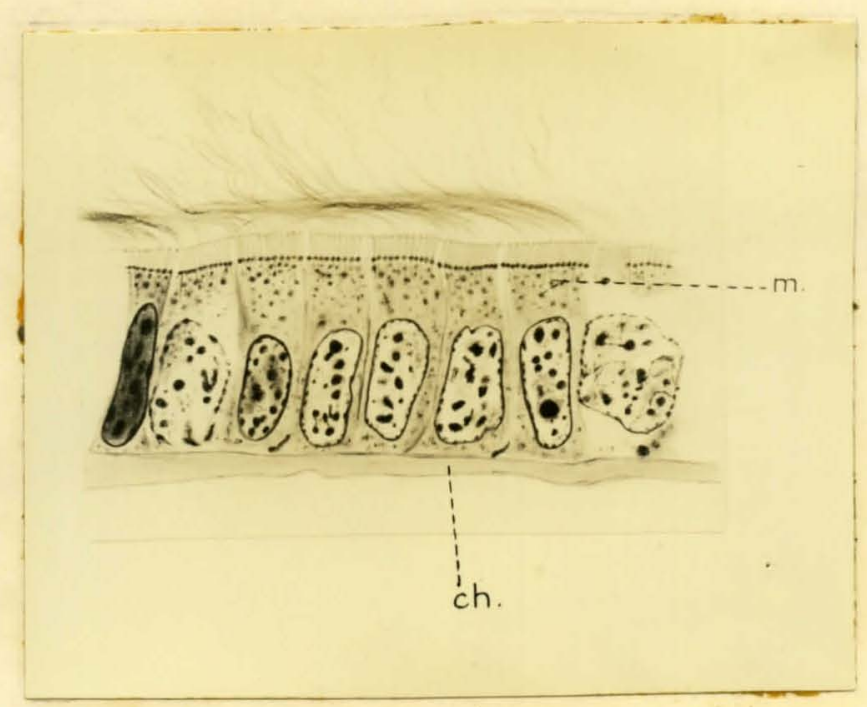

\section{FIGURE 9}

Lateral view of lateral ciliated cells. ch., chitinous support; m., mitochondria. Champy fix. Heidenhain's iron-ha ematoxylin. $\mathrm{X} 1380$.

are correspondingly narrow in cross section, averaging 
only 3 to 4 microns wide and about 9 microns high. This shows that the nuclel are rather compressed from side to side.

The cytoplasm is finely granular except for a clear area around the nucleus. There seems to be no differentiation of the cytoplasm into dense and less dense zones. Numerous granular mitochondria are present, being extremely dense in the most distal end of the cells where they are clustered around the clliary rootlets. Distal condensation of mitochondria is customary in ciliated cells. These mitochondria showed up best with the Champy-Kull stain by which they are stained deep red. They also showed well in 1ron-haematoxylin preparations and were stalned in the living tissue by Janus green B.

The free surface of the cells is covered with a cuticular border which appears striated. These cuticular striations connect two parallel rows of corpuscles of unequal size. The row directly on the surface of the cuticle is considerably smaller and less distinct than the basal layer. Both rows appear round in shape. According to Frenzel (186) basal corpuscles are found varying from the simple type with a knob at one or both ends, to the complex, consisting of up to five segments. In some of the lateral cells it looks as if there may be a third row of very minute bodies lying on the cuticular striations about halfway 
between the two layers of corpuscles.

Each of the striations appears to be continuous distally with a cilium, while from the proxinal row of bodies fibers extend deeper into the cytoplasm. These extensions do not show in all preparations of lateral cells, but were best seen in Champy fixed material. They extend about as far as the region of the nucleus. The length of the cilia, measured in dissected leaflets mounted in Euparal, is 17 microns.

The lateral cells were studied in surface view from sections and from whole mounts. The shapes of the cells in this aspect showed great variation. They ranged from the most primitive type, the hexagonal cell, to the extremely specialized, quadrangular cells. Near the free or distal tip of the leaflet the cells of the lateral band are roughly hexagonal in form. Approaching the proxinal end, the cellular elements becane elongated in the direction of the conduction of the wave, although this is at right angles to the effective beat of the cilia. Instead of being hexagonal, the cells are more or less quadrangular. The nuclei are oval in the hexagonal cells, while in the longer cells they are elongated in the same direction as the cell bodies. These lateral cells are not arranged in stralght rows in Nucula as they are in higher forms. 
Focussing on the basal bodies in surface view shows that there is a very regular and definite arrangement of the cilia in straight diagonal rows $45^{\circ}$ to the long axis of the cells (Fig. 10). These

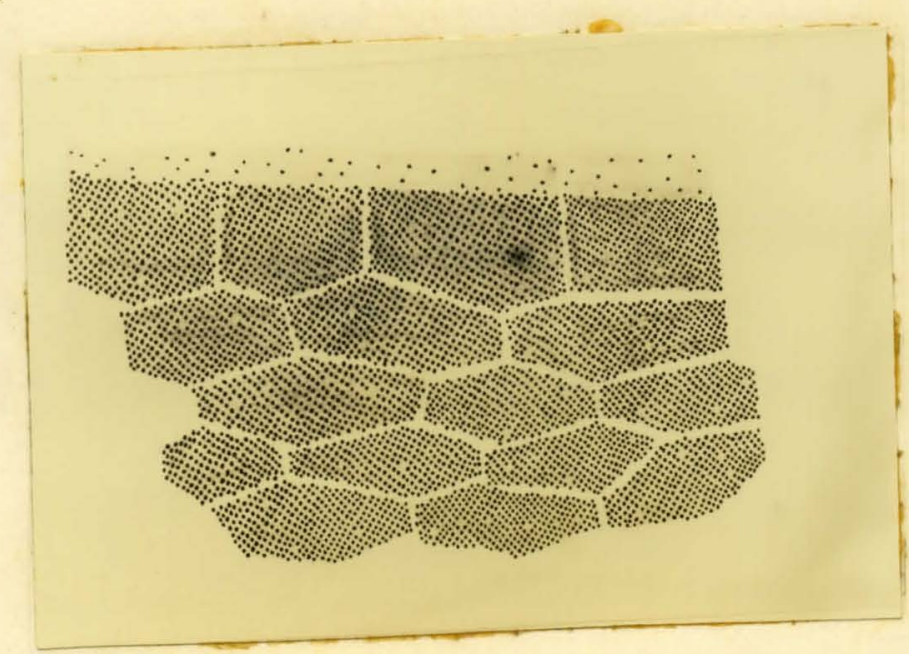

FIGURE 10

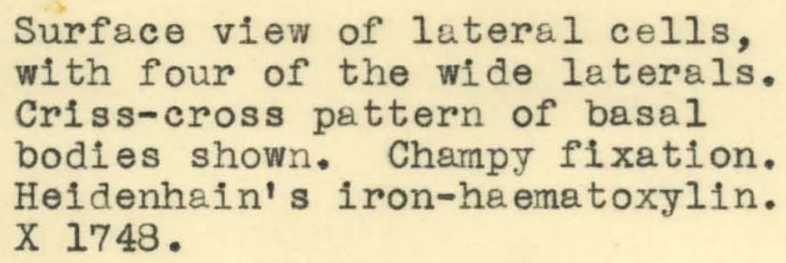

corpuscles do not appear to be aligned in only one direction, but form a perfect criss-cross surface pattern. The range of basal bodies per cell was from 210 to 280. It was estinated that there are about $5,200,000$ cilia per square millimeter of surface in these lateral cells.

Several cells undergoing mitosis were observed in the lateral epithelium, in sections and on whole mounts (Fig. 11). It does not appear that the cilia of cells 
in mitosis degenerate, to be reconstructed after division. It would seem probable that after mitosis an increase in the number of cilia comẹs about but this question has not been studied.

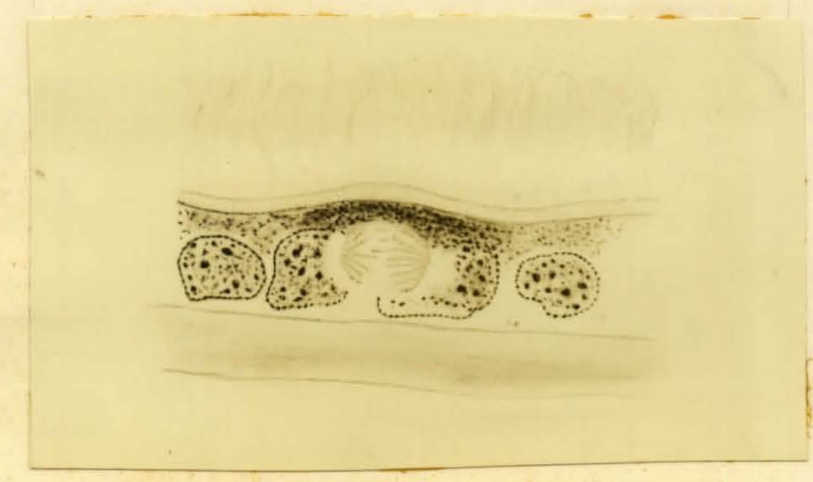

FIGURE 11

Frontal view of lateral cells showing a cell undergoing mitosis. Champy fix. Heidenhain's ironhaematoxylin. X 840 .

Forming the dorsal edge of the lateral epithelial band is an entirely different type of cell, that is, different in shape and size from the other laterals. These cells have at least three straight sides, some being almost square or rectangular, and they form a perfectly straight row (Fig. 10). They are considerably larger in dicmeter, 8 to 9 microns, and have large round nucle1. In figure 12, the second cell from the right side represents one of these large lateral cells.

Viewed from the surface, the basal corpuscles are seen in the same criss-cross pattern, but only on about two-thirds of the surface of each cell. The dorsal onethird seems bare except for a few scattered cilia. This single definite row of cells can be seen extending from 
the distal end of the leaflet all the way to the proximal end.

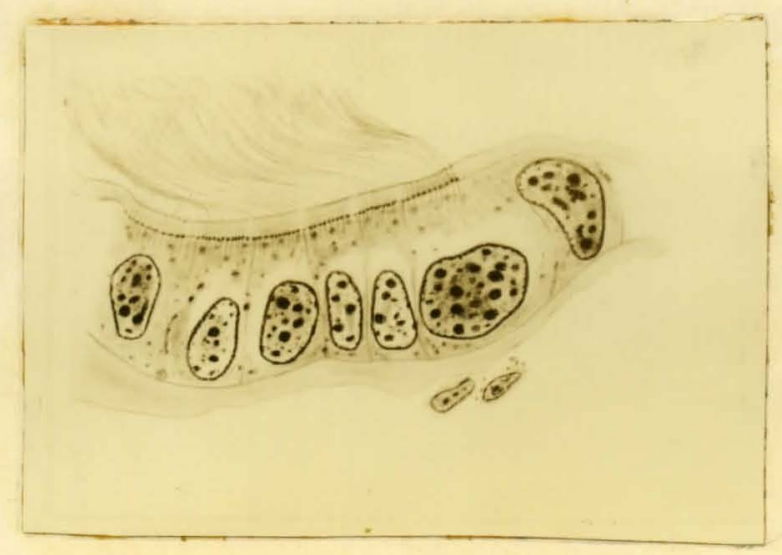

FI GURE 12

Lateral view of group of lateral cells. A wide lateral cell is shown, incompletely ciliated. Champy fix. Heidenhain's iron-haematoxylin. X 1380.

Laterofrontals. A single row of laterofrontal

cells is present on each side of the gill leaflet, ventral to the band of laterals (Fig. 6). Cell membranes were definitely seen, indicating that the laterofrontal epithelium is not a syncytium, as Grave and Schmitt (125) concluded. The function of the laterofrontal cells is to divert solid particles from the lateral cells and direct such particles toward the frontals. The effective beat of the laterofrontal cilia is toward the frontal surface.

The laterofrontal cells are tall columnar cells, measuring about 18 microns high from their cuticular surface to the chitinous supporting tissue.

Probably the most outstanding feature of these laterofrontals is the appearance of their nuclei. They are trememdous in size in lateral view, averaging approximately 14 microns high and 8.5 microns wide. 
These nuclei are also noteworthy because of their unique shapes. When viewed from above, some might be described as heart-shaped, some mitten-shaped, flask-shaped, etc., (Fig. 13).

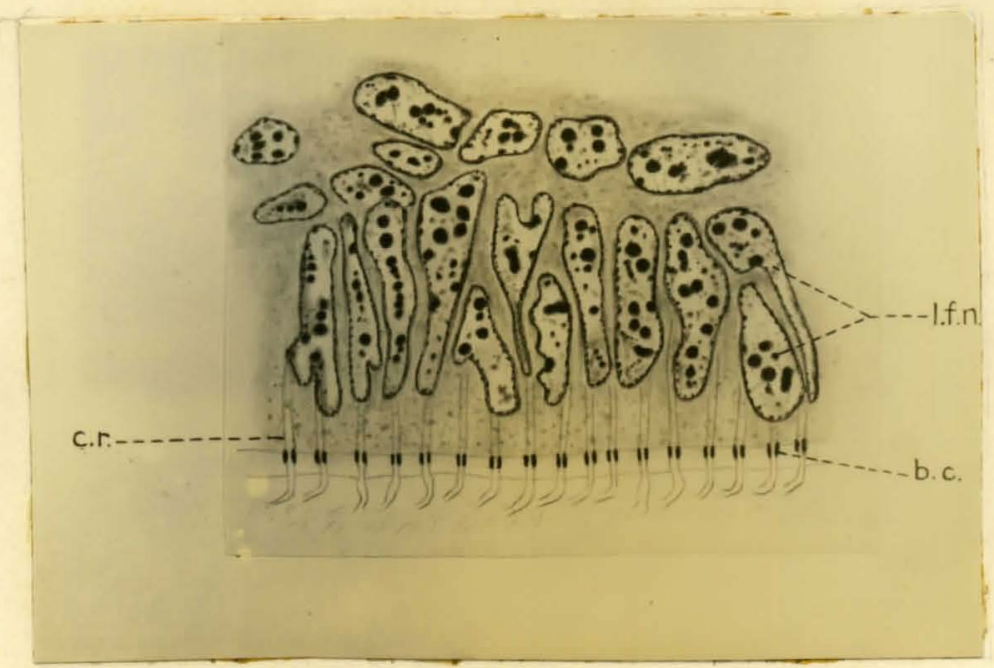

FIGURE 13

Frontal view of part of laterofrontal epithelium, showing to advantage the odd-shaped nuclei. b.c., basal corpuscle; c.r., ciliary rootlet; i.f.n., laterofrontel nuclei. Flemming fix. Heldenhain's iron-haematoxylin. X 1674.

Kindred (127) described and pictured nuclei similar in shape to those of this laterofrontal epithelium in the pharyngeal epithelium of the frog tadpole, and interpreted them as being in various phases of amitosis. Such an explanation is not tenable in this case because of the regularity of their occurrence, as every nucleus is of this form. The arrangement of the chromatin is similar to that in the laterals.

The granular cytoplasm is stained quite heavily by iron-haematoxylin. Mitochondria are present, but are not so abundant in these and in the frontals 
as in the lateral cells. The cuticle is thicker in these cells than in any of the others studied, and with Heidenhain's iron-haematoxylin also stains dark. The cytoplasm and cuticle of these cells seem to take the stain almost.as heavily as the nuclei of the laterals and frontals (Fig. 14).

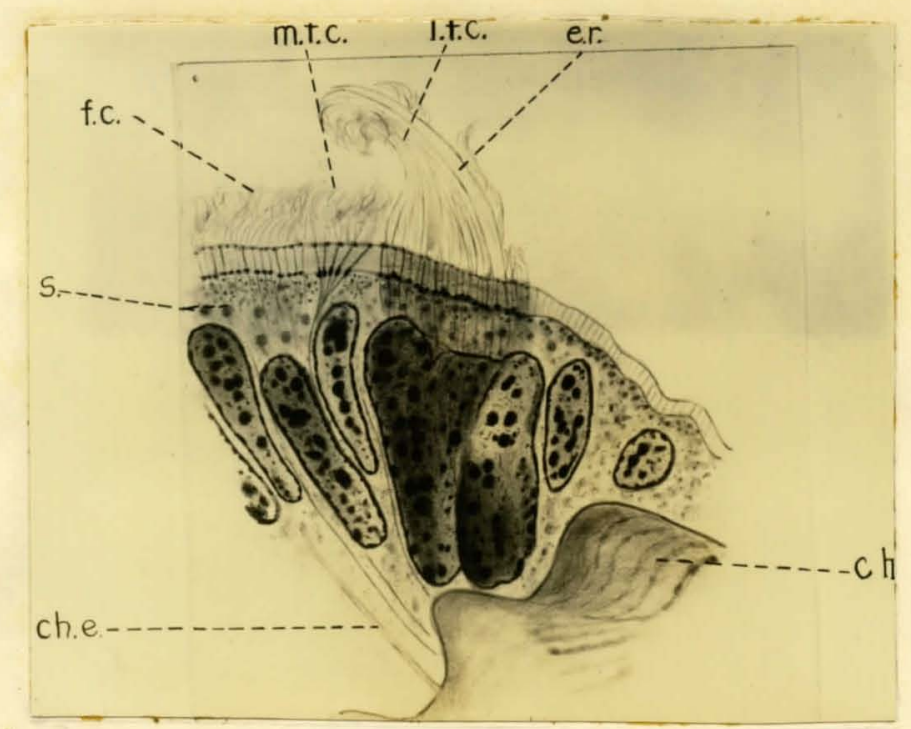

FIGURE 14

Lateral view of laterofrontal cell. ch., chitinous tissue; ch.e., chitinous extension of tissue between frontal cells; e.r., elastic rod; f.c., frontal cilia; 1.f.c., laterofrontal cilia; m.f.c., marginal frontal cilia; s., symbionts. Champy fix. Heidenhain's iron-haematoxylin. X 1748 .

Two distinct layers of basal bodies are present, the lower row larger and more distinct than those in the laterals. The cuticular striations can be seen 
quite plainly, as can the ciliary rootlets extending into the cytoplasm. Some of these internal fibrils are visible to the very base of the cells. The complicated internal ciliary apparatus described in the laterofrontal epl thelium by Grave and Schmitt ('25) and Lucas (131) was not observed in Nucula. The fibrils, one from each of the large basal bodies, descend into the cytoplasm without dividing and crosing over as these investigators mentioned in their papers. In some sections the cillary rootlets can be seen pasing close to the flat surfaces of the nuclel or between the folds of these structures as they pass toward the bases of the cells.

A highly specialized external ciliary epparatus is present which no doubt is very effective in keeping the lateral ciliated tract clear of foreign material. This mechanism consists of a membranelle of fused cilia and an elastic rod, a structure which occurs paired in each laterofrontal cell. This apparatus shows up well in transverse sections of the gill leuflets (Figs. 6 and 14). The rod is usualiy curved toward the frontal surface of the leaflet and the cllia are arranged in a single row extending from the basal bodies, making a sa11-like structure attached to a flexible mast. In frontal view all that can be seen is a pair of rather coarse cllia to each cell arising from two heavy rodlike basal bodies. These rods are about 12 microns long, as measured in dissected leaflets. 
In surface view, the laterofrontal cells are rectangular in shape and the basal corpuscles appear as two very thick black lines. Engelmann (130) and Saguchi (117) both saw this structure and described it as being composed of fused basal bodies. Saguchi mentioned the tendency for basal bodies to fuse and said that in some clilated cells faint fibrils can be seen connecting the corpuscles in the same row.

In the liying specimen, one can observe individual or groups of laterofrontal cells contract when they are touched by foreign particles such as carmine granules, and these contractions throw the particles up toward the frontal cells. No regular wave of contraction runs up or down the rows of laterofrontal cells.

Frontals. The frontal cells occur in a tract about five cells wide along the frontal or ventral edge of the leaflets (FIg. 6). These clliated cells are all of one type, there being no food-sorting mechanism presont such as Atkins ('36) discovered in the frontal epithelium of Nuculana, consisting of coarse and fine frontal clila.

In transverse sections of the leaflets (FIg. 6) the cells are seen in frontal section. They are tall, very narrow columnar elements, narrowing toward their basal portion, and rest directly on the chitinous skeleton. Their nuclei which lie in the upper twothirds of the cells are often pear-shaped, the broader 
end being toward the surface.

Two rows of basal bodies are again present, but not so conspicuous or well-defined as in the laterals and laterofrontals. The cillary rootlets are especially prominent in the frontal cells, of ten being traceable to the chitinous framework. In some of the transverse sections of the leaflets narrow strands of the chitinous material could de seen extending up between the frontal cells. This was noticeable in a few of the iron-haematoxylin preparations, but particularly clear in the sections stained by the Champy-Kull stain.

The granular cytoplasm stains gray with Heldenhain's iron-haematoxylin, with the mitochondria showing up black. These mitochondria are clustered around the clilary rootlets just beneath the cuticle as in the lateral cells.

Probably the most conspicuous structure noticed in these cells was fuirly large round light-greenish bodies, mostly in the supranuclear cytoplasm. From their appearance it is held likely that these bodies are intracellular symbionts. Their presence was later noted also within the blood spaces of the filaments. They were also found in some of the non-ciliated cells near the dorsal surface of the leaflets, and a few in the laterofrontal cells. These structures were plainly seen even in the unstained sections mounted in Euparal after Champy fixation. 
These bodies showed considerable variation in size and form. A few that were measured ranged from .98 to 2.6 microns in diameter. Although the majority of them are spherical, some showed protruberances. A number of the bodies appeared to be light in color in the center with patches of darker color around the periphery. In some, this darker condensation was in clumps, and quite often gave the appearance of small buds. In fact, several of the structures greatly resembled yeast buds, as shown in the accompanying sketches.

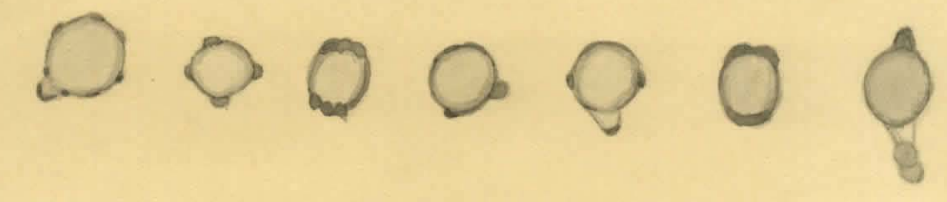

These were all observed in non-ciliated cells of the dorsal midrib portion of the gill.

Most of the so-called symbionts present in the frontal cells are located distal to the nucleus, although occasionally some were noted in the cytoplasm basal to the nucleus. These were usually quite a bit smaller than those in the supranuclear cytoplasm. These smaller bodies probably enter the frontal cells from the blood spaces where they are carried by the ameboid blood cells, inasmuch as these blood cells often appeared full of the small greenish bodies. Many of these symbiotic structures were observed lying free in the blood spaces, and they also were seen in 
small canals in the chitinous supporting tissue of the leaflets directly beneath the frontal cells. These canals appeared to open at the basal portion of the frontal cells and it is probably through them that the symbionts gain access to the cells.

From the surface, the frontal cells are hexagonal in shape. They measure about 10 microns by 7 to 8 microns, with their long axis lying in the direction of the effective beat of the cilia (Fig. 15). Basal bodies

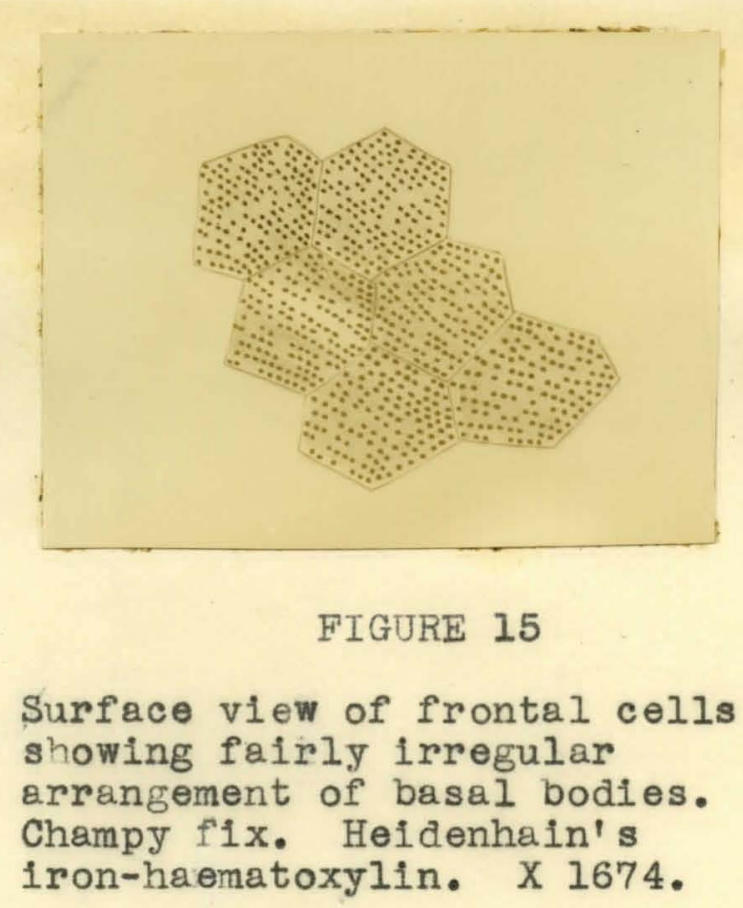

could be seen and counted, about 125 to a cell. The cilia are not arranged in a regular geometrical pattern of straight or diagonal rows as in the laterals, but form irregular short rows, all seeming to proceed roughly in one direction, in the length of the leaflet. 
The frontal cilia all lash in the same direction, those on the outer leaflets beating toward the midrib of the gill, and those on the medial leaflet beating toward the distal or inner border: They are continuous across the ventral surface of the gill from one leaflet to the opposite one. These cilia are about 10 microns long.

When carmine particles in sea water are dropped on the frontal cells they are propelled by the cilia across the frontal surface of the gills and collect on the medial edge where they pass anteriorly and are taken up by the palp appendages.

Between the laterofrontal and frontal epithelia on each side of the filament is a single row of narrow, elongated, quadrangular cells which I have chosen to call marginal frontals (Figs. 6 and 14 and diagram B).

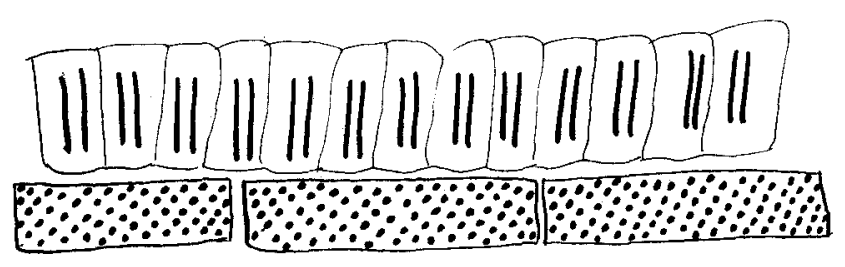

\section{FIGURE B}

Surface view of three marginal frontal cells. Surface view of laterofrontals also shown. X 60 . 
These marginal frontal cells are quadrangular whon viewed from above. They are long and narrow, their length being about 5 to 6 times their width. The cilia are arranged in parallel diagonal rows, usually five cilia to a row. The average number of cilia to a single cell is 100 to 150. The symbionts are present in these cells also.

In transverse sections these cells stand out because of several features. The basal bodies are especlally clear. There are five corpuscles in the superficial layer on the cuticle and five directly beneath. The cuticular striations connecting these two rows of basal bodies stand out very sharply. Five cillary rootlets can be plainly seen entering the cytoplasm for a short distance, one from each of the proximal corpuscles. These five fibrils converge to form a fan-shaped structure. In some cells it appears that a single fibril extends from the point of this cone more deeply into the cytoplasm.

The lower row of basal bodles looks as if each corpuscle may be composed of two segments, the lower segment large and elliptical in shape, while the small upper segment appears round. The cuticle is unstriated for a short space on either side of these cells.

In transverse sections it appears as if these narrow cells do not extend all the way down to the supporting tissue as do the frontals and laterofrontals. 
The distinctive internal apparatus of these cells would seem to indicate that they have a special function. Since they were discovered only after living material was no longer avaflable it was impossible to find out their function. 
$V$ Discussion 
Discussion

Probably the chief interest of this present cytological study. of cillated cells lies in the discovery of the tendency of the cells to become specialized. This is especially noticeable in the lateral ciliated epithelium of the gills of Nucula, a primitive protobranch, when compared with similar cells in Ostrea, a highly specialized lamellibranch. Each type of ciliated cell of the gill of Nucula bears a general resemblence to the corresponding type in Ostrea, but the evidences of differentlation are most apparent in a comparison of the lateral epithelia of the two gills. In Ostrea, the cells are more highly modified as shown by their shape, arrangement in definite rows, variation in width of the cells from row to row, and arrangement of the basal bodies within the cells.

The gills of Nucula show considerable specialization within their own lateral epithellum in the shapes of the lateral cells. These laterals vary from the most primitive type, the hexagonal cell, to four-cornered cells, a form of eplthelial cell not often encountered in the animal kingdom. In Ostrea this specialization is completed; all of the luteral cells are of the higher type with straight sides and $90^{\circ}$ angles where the sides me日t.

As previously mentioned, the elongation of the 
hexagonal cells occurs in the plane of the conduction of the ciliary wave, even though this is at right angles to the effective beat of the individual cilia. This would seem to indicate that the cells become modified to effect a more efficient system of wave conduction.

Ostrea has two rows of lateral cells which are still further differentiated: the two rows of very narrow cells, one row at each edge of the band of laterals. There is but one single row of cilla present on these cells, running parallel to the longer dimension of the cells. The proputsion of water is transverse to this. It is evident that these cells could not of fer much assistance in actual movement of the wave, but probably are present for the purpose of keepling the area around the lateral band clean of debris.

It is interesting to speculate as to just in which direction, in relation to the surface dimensions of the hexagonal cells, their change in form took place. From observations on a great number of cells of the lateral epithellum of Nucula, It seems reasonable to state that there are three or four steps in the gradual transformation of a hexagonal into a quadrangular cell. A typical example of what probably occurs in this transition 
is diagrammed in Fig. C., whtch shows the hexagons, $A$ and $A^{l}$, after several changes, emerging as perfect four-sided figures in figures $E$ and $E^{l}$.

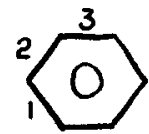

A

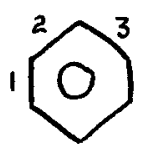

$A^{\prime}$

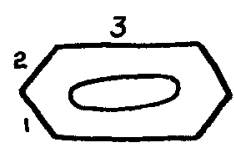

B

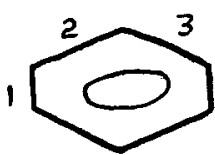

$B^{\prime}$

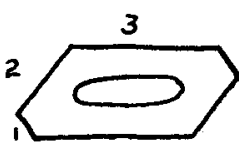

C

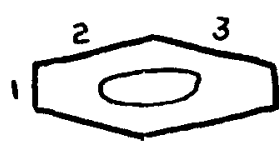

$c^{\prime}$

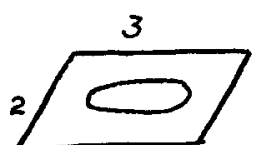

D

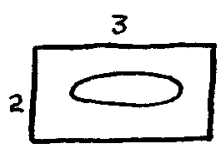

$E$

FIGURE C

In the diagram the sides of each flgure are numbered, making it easier to follow the successive stages. The round nucleus of the hexagon likewise is elongated in the same plane as the cell bodies. In Nucula, most of the lateral cells are of the $B, B^{1}$, $c$, and $\mathrm{C}^{\mathrm{I}}$ types.

In Ostrea, all of the lateral colls have straight sides, with $90^{\circ}$ angles, lie in perfectly straight rows, and are probably still more highly advanced in that the rows are differentiated from each other in width. Figure $D$ is a digrammatic representation of the pattern of laterals in Ostrea. Rows 1 and 6 have only a single row of clila. Rows 2 and 3 are next in width. Then comes row 5, and widest of all is row 4 . 


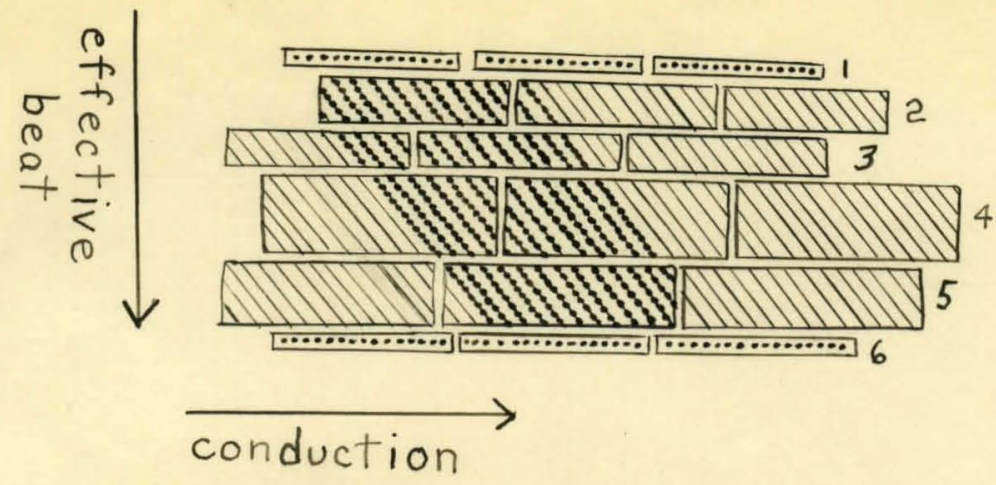

FIGURE D

The row of large nearly square cells mentioned previously are the only quadrangular lateral cells present in Nucula, and the only laterals to fall into a definite row. These features, plus the fact that these cells are unique in being only partly ciliated would naturally lead to the supposition that they are a transition stage. It is possible that these cells are losing some of their cilia in the process of decreasing in diameter, to become narrow like the laterals in higher forms.

In so far as the efficiency of wave conduction is concerned, it seems logical to conclude that cells in definite rows and having parallel straight sides in the plane perpendicular to the wave would be more effective than hexagonal cells (Fig. E).

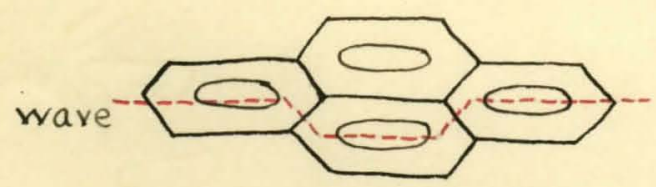

a

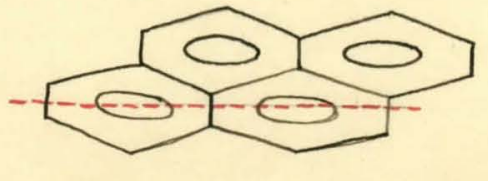

b

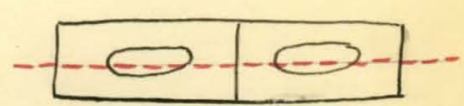

c 
Lucas ('3I), referring to the coordination Impulses of cillated cells, says "it is reasonable to regard the walls of adjoining cells as synapses in the conduction pathwey. It is generally known that transmission across a synapse lowers the conduction time (of the impulse), etc." It seems not unreasonable to assume that the cell walls may also cause some slight retardation in the conduction of the clilary wave. Worley ('34), after making incisions through the ectoplasm of Paramecia and Stentors, came to the conclusion that metachronal and reversal impulses are transmitted through this ectoplasm. Assuming this to be true, it appears likely that the cell walls in Fig. E, (b) and (c), would offer less resistance and a more direct pathway to the conduction of the protoplasmic impulse for the clilary wave than the type in (a). In this latter diagram, (a), the wave would have to follow a zig-zag course, while in (b) and (c) the course would be in a perfectly straight line.

The arrangement of the clila in surface view is another feature of the lateral cells that presents evidence of modffication and specialization. The pettern in Nucula has been described, the cilia ranged in rows approximately $45^{\circ}$ to the long axis of the cells, giving a cross-hatched appearance. In Ostrea, the 
cilia are assembled in single complete diagonal rows also $45^{\circ}$ to the long axis of the cells. Engelmann (180) explains the significance of this angular arrangement of the cilia: the mechanical advantage which this disposition of the cilia affords lies in the fact that each individual cilium has more room for play between It and the cilia in front and behind it than if they were arranged in straight rows parallel to the greater length of the cell. Fig. F is a diagram of these two possible arrangements.

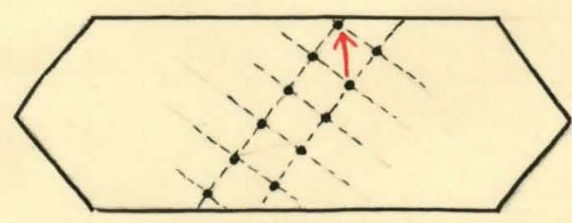

a
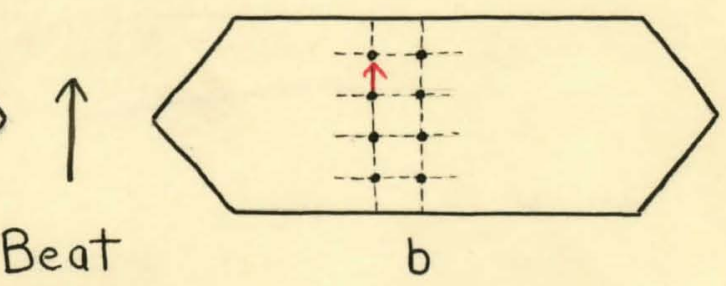

FIGURE F

Thus in (a) the distance of the ciliary beat is the diagonal of the square; in (b) it is the side of a square.

The area of a single lateral cell in surface view in Nucula is about twice as great as in Ostrea. Approximately the same cilia-cell area ratio holds for the two types of lateral cells. However, the number of cilia per square milimeter is very nearly the same in Nucula and Ostrea: Nucula having approximately 5,200,000 and Ostrea 5,000,000 per 
square mililmeter.

- In Ostrea, the basal bodies appear larger in diameter than they do in Nucula, and the corpuscles form almost solid rows, running diagonally across the cells in only one direction, giving the appearance of a coarse, flat file. They appear to lie very close to each other; In fact, they seem to be almost touching. The spaces between the individual parallel rows of c111a, however, are quite wide. Due to this distribution of the cilia, the rows look more efficient than those of Nucula, with 1 ts open network, and probably form a more effective physical mechanism for moving the water.

These solid rows of cilia standing like palisades with aisles between them appear to form diagonal channels along which the water might be moved. The width of the entire band of laterals in Ostrea and the number of rows of cells is much less than in Nucula. In Ostrea, there are six rows of cells, including the two very narrow rows, and the whole lateral band measures only 8 to 9 microns across. In Nucula, the epithelial band contains 7 or 8 rows of considerably larger cells and it is 6 to 7 times the width of that in Ostrea. One could as sume that the narrowing of the lateral bund in Ostrea is correlated either with a greater efficiency in water-moving ability of the cells of the latter, or 
that the oxygen absorption in Ostrea, with its internal gill channels, is more efficient. One must, however, remember that the gills of Ostrea are relutively huge structures and that Ostrea is a sedentary animal, whereas Nucula moves about constantly. Only a detalled physiological study of the relative oxygen requirements of Nucula and Ostrea could give a definite answer to this question.

The laterofrontal cells in Nucula are noteworthy because of their odd-shaped nuclei and unusual external ciliary apparatus. In Ostrea, the outstanding feature of these cells is the complex system of internal fibrils. This structure has been described in detail by Grave and Schmitt (125) in the gills of Lampsilis and Quadrula, and by Lucas ('31) in the laterofrontal cells of Mytilus, Amblema, and Megalonaias. This apparatus, seen only in frontal sections, consists of two diverging fibrils arising from esch of two visible basal bodies and passing to opposite sides of the oval nucleus where they are jolned by corresponding fibrils from the other basal body. These rootlets were traced in the cytoplasm only as far as the region of the nucleus. Only two cilia are perceptible in these cells, too.

Viewed in laterel sections, these laterofrontal cells look quite different. They are topped with a 
row of cllia, and an equal number of clliary rootlets can be seen descending, parallel to each other and one from each basal body, into the cytoplasm.

No complex arrangement such as this is present in the laterofrontal cells of Nucula. The intracellular fibrils, one from each basal corpuscle, can be easily traced deep into the cytoplasm. In frontal view of the epithellum (Fig. 13) these fibrils are visible between arjacent nuclei. In frontal view (Fig. 14) the clilary rootlets are plainly seen in the supranuclear cytoplasm and seem to disappear either between adjacent nuclel or within the folds of the nucleus itself. The presence of fibrlis below the nucleus was apparent in some cells, reaching to the basal portion of the cells.

The laterofrontal cilia in Nucula are fused into a membrane which is fastened to a flexible rod. This entire structure is seen only in lateral view; in frontal view only the cirrus is visible. This.rod lashes toward the frontal cells in which direction it propels solid particles that might otherwise congest the lateral ciliated tracts. Just dorsal to the elastic rod on each laterofrontal cell is a tuft of short cilia which also look as if they ure attached to the rod. They may serve to help return the clrms to the vertical position after its effective stroke. 
In Nucula, the palps and palp appendages take care of most of the food movement, a function which is performed to a larger extent in Ostrea by the frontal clilated cells of the gills. Due to this greater activity of the frontal cells in Ostrea, it is likely that they would be in a more advanced stage than those of Nucula.

Seen in surface view the frontal cells of both animals are hexagonal in shape. The basal bodies per cell are undoubtedly fewer in Ostrea, but this decrease in number may be compensated for by an apparent increase in diameter of the basal bodies and the stoutness of their cilia which seems to be apparent in both the living and fixed material. It may be that a decrease in actual number of cilia In an epithellal band is accompanied by an increase in their size and efficiency.

No great regularity of cilia or cell rows occurs in the frontals of either Nucula or Ostrea. Seen from the surface, the basal bodies are ranged in short, irregular rows. In Nucula, these groups, or rows, of basal corpuscles lie more or less parallel in the length of the cell and have their effective beat in the direction of conduction of the wave across the gill to the medial border. 
In Ostrea, the rows look even more frregular. They do, however, form a very efficient food-gathering apparatus. The frontal cells of Ostrea, lying close to the laterofrontals, have their cilia in irregular rows pointing partly toward the middle line of each filament and downward, whereas those cells in the midilne have the rows pointing downward (Figure $G$ ).

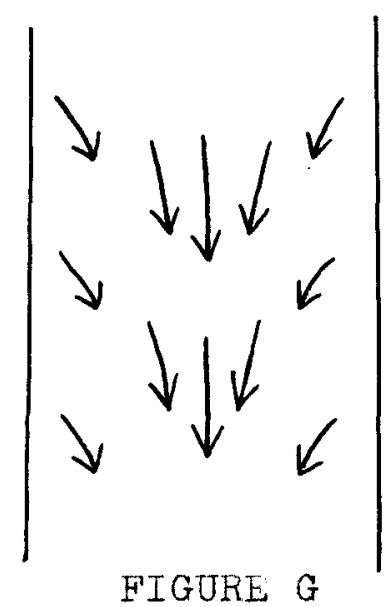

On dropping carmine particles onto the frontal's surface one can clearly see them moving as indicated in the above diagram. In Nucula no such high specialization has yet taken place.

The symbionts mentioned previously were first noticed in the frontal cells of Nucula. Later they were observed in fewer numbers in the laterofrontal cells, in the blood spaces of the leaflets, and some within the ameboid blood cells. The last mentioned site suggests the possibility that these blood cells may be the means of transportation of the symbionts 
Into the epithelium.

There is a slight variation in size and shape of the symbionts in different cells. Some look as if they are segmented, and may be in the process of dividing. They are light green in color in unstained sections, and in slides stained with Heidenhain's iron-haematoxylin look greenish gray. They do not take the stain, however, as mitochondria or the Golg1 apparatus would.

References on symbionts in the molluscs in literature are rather meager. Negri, in 1874, and Brandt, in 1883, discovered the presence of symblotic algae in epicermal cells of the gastropod, Elysia. Brandt 1solated the structures and was successful in growing them in culture media.

In 1886, Frenzel wrote an interesting paper on the finer structure of the ciliary apparatus, describing particularly the eplthelium of the digestive tract of snalls. This article is illustrated with beautiful colored lithographs which show, in the supranuclear cytoplasm, green oval bodies resembling

1. Buchner, Paul. Tier und Planze in Intrazellularer Symbiose. Gebrdder Borntraeger, Berlin. 1921. 
in color, form, and size the structures seen in Nucula. Frenzel did not mention these bodies at all, confining his remarks exclusively to the ciliary apparatus. Further study upon the so-called symbionts of Nucula is indicated. 
VI Summery 


\section{Summary}

Evidences of cellular specialization discovered in the clilated epithelia of the gills of Nucula compared with corresponding cells of Ostrea are:

1. Lateral hexagonal cells of Nucula and their nuclei tend to elongate in the direction of conduction of the wave. Nucula is the first bivalve described having hexagonal leteral cells, and these are not arranged in strolght rows. These irregular rows, seven to elght in number, form a wider band than in the higher forms. An approach is made toward the quadrangular lateral cell and arrangement in straight rows. This is practically accomplished in the most dorsul row of lateral cells of Nucula. AIl the lateral cells of Ostrea, a higher form, are quadrangular with straight sides and $90^{\circ}$ angles where the sides meet. Also, lateral cells of Ostrea lie in definite rows.

2. The cilia of the lateral cells in Nucula form a criss-cross surface pattern; in Ostrea, they lie in continuous diagonal rows. The arrangement in Ostrea is probably more efflclent for the movement of water than in Nucula, as the lateral band is only one-sixth 
as wide.

3. Laterofrontal cells in Nucula have conspicuous nuclei and specialized external ciliary apperatus, consisting of an elastic rod and

a sa1l-like nembranelle made up of fused cilia. In Ostrea, the laterofrontal cells are notable because of their intricate system of intracellular ciliary rootlets.

4. Most outstanding feature of the frontal cells of Nucula was the presence of a great number of symbionts in the cytoplasm. They are present also to a lesser extent in the laterofrontal cells.

5. A type of cell not previously described was discovered lying between the frontals and laterofrontals. These cells are quadrangular, elongated, with basal bodles lying in diagonal rows, five to each row. From each basal body a fibril extends into the cytoplasm. These fibrils converge, forming a cone-shaped internal apperatus above and to one side of the nucleus. Their quadrangular, elongated form, the arrangement of their cilia, and their internal apparatus indicate that they are a highly specialized type of epithelial cell. 
VII References 


\section{References}

Atkins, Daphne. 1936. On the Clliary Mechanisms and Interrelationships of LameIIIbranchs. I. Some New observations on Sorting Mechanisms in Certain Lamellibranchs. Quart. Journ. MIc. Sci., vol. 79, pp. 18I-308.

1937. On the Ciliary Mechanisms and Interrelationships of LameIIbranchs. II. Sorting Devices on GIIIs. Quart. Journ. Mic. Sci., vol. 79, pp. 339-373.

Bollng, Leroy R. 1935. Regeneration of Nasal Mucosa. Arch. of Otolaryng., vol. 22, pp. 689-724.

Certer, G. S. 1923. On the Structure of the Laterofrontal Cilia of the Gilis of Nytilus. Proc. Roy. Soc. Iond., vol. 96, pp. 115-122.

1926. On the Nervous Control of the Velar Cilia of the Nudibranch Veliger. Brit. Journ. Exp. BIol., vol. 4, pp. 1-25.

1928. On the structure of the cells Bearing the Velar Clila of the Nudibranch Veliger. Brit. Journ. Exp. Biol., vol. 6, pp. 97-109.

Drew, Gilman A. 1901. The Life History of Nucula delphinodonta (Mighels). Quart. Journ. Mic. ScI., vol. 44, pp. 313-393.

Engelmann, Th. W. 1830. Zur Anatomie und Physiologie der Flimmerzelien. PfIUgerts frch. f. d. ges Phys., Bd. 23, pp. 505-535.

Frenzel, Johannes. 1886. Zum feineren Bau des Wimperapparates. Arch. fthr Mik. Anat., Bd. 28, pp. 53-78.

Grave, Caswell and Schmitt, Francis. 1925. A Mechanism for the Coordination and Regulation of CIIlary Movement as Revealed by Microdissection and Cytological studies of Cillated Cells in Molluscs. J. Morph. and Physiol., vol. 40, pp. 479-515.

Gray, J. 1924. Mechanism of Ciliary Movement. IV. The Relation of Ciliary Activity to Oxygen Consumption. Proc. Roy. Soc. Lond., B, vol. 96, pp. 95-115. 
Gray, J. 1931. A Textbook of Experimental Cytology. Macmilian Co. pp. 463-486.

Kellogg, James L. 1915. Ciliary Mechan1sms of Lamelilbranchs with Descriptions of Anatomy. J. Morph., vo1. 26, pp. 625-701.

Kindred, James E. 1927. Cell Division and Ciliogenesis in Clilated Epltholium of Pharynx and Esophagus of the Green Frog, Rana clemitans. J. Morph., vol. 43, pp. 267-299.

Lucas, Alfred M. 1931. An Investigation of the Nervous System as a Posstble Factor in the Regulation of Clliary Activity of the Lamellibranch GII. J. Morph. and Physiol., voI. 51, pp. 147-193.

1932. Coordination of Clliary Movement. J. Morph., vol. 53, pp. 243-276.

McDonald, James R., Lelsure, C. E., and Lenneman, E. E. 1928. New Principles in the Control of the Activity of Cllated Epltholium. Trans. $\mathrm{Hm}_{\mathrm{m}}$ Acad. of Ophtha1. and Otolaryng., pp. 318-350.

Mitsikuri, K. 1881. On the Structure and Significance of Some Aberrent Forms of Lamelifbrench Gills. Quart. Journ. MIc. Sc1., vol. 21, pp. 595-608.

Peck, R. Holman, 1877. Minute Structure of the Gills of Lamellibranch MoIIuscs. Quart. Journ. MIC. Sc1., v01. 17, pp. 53-65.

Prenant, A. 1911-13. Les Appareils Ciliés et Leurs Derivés. J. de I'Anat. et de la Physiol., T. 48, pp. 545-547, 1911; T. 49, pp. 88-89, 1912; T. 49, pp. 506-525, 1913.

Proetz, Arthur, 1933. Studies of Nasal Cilia in Living Mamma Is. Ann. Ot., Rhin., and Laryng., vol. 42., pp. $778-788$.

1934. The Effects of Certain Drugs on Living Nasal Cillated Epithellum. Ann. Ot., Rhin., and Laryng., vol. 43 , pp. 450-463.

and Pfingsten, Marian. 1936. Clliated Nasal Epithellum: Its Culture in Vitro. Ann. Ot., Rhin., and Laryng., vol. 45, pp. 400-404.

Rice, Edward L. 1908. Gill Development in Mytilus. Biol. Buil., vol. 14, pp. 6I-77. 
50

Sagucht, S. 1917. Studies on Ciliated Cells. J. Morph., vol. 29, pp. 218-279.

Warley, Leonard G. 1934. Ciliary Metachronlsm and Reversal in Paramecium, Spirostomum and stentor. J. Cell. and Comp. Physiol., vol. 5, pp. 53-71.

Wyman, Jeffries, Jr. 1925. Neurold Transmission in Collated Epithelium. J. Gen. Physiol., vol. 7, pp. 545-559.

Yonge, C. M. 1923. Studies on the Comparative Physiology of Digestion. I. Mechanism of Feeding, Digestion, and Assimilation in the LamellIbranch, My. Brit. Journ. Exp. Biol., vol. 1, pp. 15-65. 